\title{
Jurnal
}

p-ISSN 2621-797X ; e-ISSN 2746-6841 DOI:10.32493

Jurnal Disrupsi Bisnis, Vol. 4, No. 5, September 2021 (463-468)

http://openjournal.unpam.ac.id/index.php/DRB/index

\section{Analisis Non Performing Loan (NPL) Pada Bank BRI Tbk}

\author{
Astri Aristianti ${ }^{1}$, Nafisah Nurulrahmatiah ${ }^{2}$, \\ ${ }^{1,2}$,Sekolah Tinggi Ilmu Ekonomi STIE Bima, Kota Bima. \\ Astridaristianti17.stiebima@gmail.com¹; Nafisahrachmatia@gmail.com²
}

Received 27 Agustus 2021| Revised 10 September 2021 | Accepted 28 September 2021

*Korespondensi Penulis

\begin{abstract}
Abstrak
Penelitian ini bertujan untuk Untuk mengetahui Seberapa besar NON PERFORMING LOAN (NPL) pada PT. Bank Rakyat Indonesia (BRI), tbk, Penelitian ini merupakan penelitian Deskriptif Penelitian deskriptif yaitu suatu metode dalam penelitian yang dilakukan untuk mengetahui nilai variabel mandiri, baik satu variabel atau lebih (independent) tanpa membuat perbadingan, Adapun instrument penelitian yang digunakan dalam mengumpulkan data adalah laporan keuangan PT. Bank BRI Tbk berupa laporan rasio keuangan dari tahun 2010-2019, Populasi dalam penelitian ini adalah berupa laporan keuangan pada PT BANK BRI Tbk. Sejak tahun 1989-2019 selama 30 tahun Adapun teknik pengambilan sampel yang digunakan oleh peneliti dalam penelitian ini adalah teknik purposive sampling, Jenis data yang di gunakan dalam penelitian ini adalah Data Kualitatif, Teknik pengumpulan data yang di gunakan yaitu (a) studi pustaka (b) dokumentasi, Teknik Analisis data menggunakan Analisis Keuangan dan uji t satu sampel independent, hasil penelitian ini adalah NON PERFORMING LOAN (NPL) pada bank BRI berada dibawah standar kriteria yang ditetapkan 5\% di katakana Baik.
\end{abstract}

Kata Kunci: Non Performing Loan (NPL)

\section{Abstract}

This study aims to find out how much Non Performing Loan (NPL) at PT. Bank Rakyat Indonesia (BRI), tbk, This research is descriptive research. Descriptive research is a method in research conducted to determine the value of independent variables, either one or more variables (independent) without making comparisons. The research instrument used in collecting data is financial statements of PT. Bank BRI Tbk in the form of financial ratio reports from 2010-2019. The population in this study is in the form of financial statements at PT BANK BRI Tbk. Since 1989-2019 for 30 years The sampling technique used by researchers in this study is purposive sampling technique, the type of data used in this study is qualitative data, the data collection technique used is (a) literature study (b) documentation, data analysis technique using financial analysis and one independent sample $t$ test, the results of this study are Non Performing Loan (NPL) at BRI bank which is below the standard criteria set at 5\% in the word Good.

Keywords: Non Performing Loan (NPL)

http://openjournal.unpam.ac.id/index.php/DRB/index 


\section{PENDAHULUAN}

Bank merupakan lembaga keuangan, disamping memberikan jasa dalam lalu lintas pembayaran dan peredaran uang, usaha pokok bisnisnya adalah memberikan pelayanan kredit kepada para nasabahnya. Secara tradisional penyaluran kredit merupakan sumber pendapatan utama bagi suatu bank. Bank sebagai entitas usaha akan berusaha memperoleh keuntungan yang tinggi. Bank dengan keuntungan yang semakin tinggi mengindikasikan bank tersebut semakin sehat (Hosen dan Rahmawati, 2014). Namun selama dua tahun terakhir dunia dihadapkan pada munculnya wabah Covid-19 yang bukan saja berimbas pada sektor kesehatan namun juga pada sector perekonimian. Bank merupakan salah satu lembaga keuangan yang terdampak pandemi Covid-19. Dampak yang dihadapi dunia perbankan adalah terjadinya peningkatan kegagalan kredit pada bank. Sedangkan salah satu tujuan utama bank adalah memberikan kredit untuk memperoleh pendapatan bunga.

Kegagalan kredit adalah kegagalan atau keterlambatan debitur dalam pengambilan angsuran pokok dan bunga pinjamannya. Rasio kredit yang bermasalah ini disebut Non Performing Loan (NPL). Bank dengan NPL yang semakin tinggi menunjukkan pengelolaan kredit yang semakin jelek (Haryanto, 2018). Non Performing Loan (NPL) adalah kredit yang didalamnya terdapat hambatan yang disebabkan oleh 2 (dua) unsur yakni dari pihak perbankan dalam menganalisis maupun dari pihak nasabah yang dengan sengaja atau tidak sengaja dalam kewajibannya tidak melakukan pembayaran (Kasmir, 2013). Kredit bermasalah diakibatkan oleh ketidaklancaran pembayaran pokok pinjaman dan bunga yang secara langsung dapat menurunkan kinerja bank dan menyebabkan bank tidak efisien.

Kasus terkait kredit macet pasti akan terjadi pada semua bank, salah satunya adalah bank BRI dimana besar jumlah kredit macet atau Non Performing Loan (NPL) pada Bank rakyat indonesia (BRI) dari tahun 2010 sampai dengan tahun 2019 mengalami peningkatan yang dapat di lihat di tabel di bawah ini:

Tabel 1. Data Non Performing Loan (NPL) pada Bank rakyat indonesia (BRI)

\begin{tabular}{ccc} 
Tahun & Kredit Bermasalah & Total Kredit \\
\hline 2010 & $\operatorname{Rp~6,865,709}$ & $\operatorname{Rp~246,964,238}$ \\
\hline 2011 & $\operatorname{Rp~6,522,422}$ & $\operatorname{Rp~283,583,198}$ \\
\hline 2012 & $\operatorname{Rp~6,203,863}$ & $\operatorname{Rp~348,227,188}$ \\
\hline 2013 & $\operatorname{Rp~6,654,494}$ & $\operatorname{Rp~430,617,872}$ \\
\hline 2014 & $\operatorname{Rp~8,271,125}$ & $\operatorname{Rp~490,402,708}$ \\
\hline 2015 & $\operatorname{Rp~11,267,382}$ & $\operatorname{Rp~558,436,016}$ \\
\hline 2016 & $\operatorname{Rp~12,882,913}$ & $\operatorname{Rp~635,291,221}$ \\
\hline 2017 & $\operatorname{Rp~14,862,646}$ & $\operatorname{Rp~708,001,045}$ \\
\hline 2018 & $\operatorname{Rp~17,232,672}$ & $\operatorname{Rp~804,338,433~}$ \\
\hline 2019 & $\operatorname{Rp~23,773,591}$ & $\operatorname{Rp~907,388,986}$ \\
\hline Sumber $:$ www.bankbri.co.id
\end{tabular}

Dari tabel 1 di atas dapat di lihat bahwa nilai dari kredit bersamalah dan total kredit yang di keluarkan oleh bank BRI Tbk terus melangalami peningkatan dari tahun ketahunya, kredit bermasalah yang terjadi pada tahun 2010-2019 terus meningkat yang pada tahun 2010 menyentuh angka Rp6,865,709 naik menjadi Rp23,773,591 pada tahun 2019, hal tersebut berbading lurus dengan jumlah total kredit yang keluarkan oleh bank BRI yakni pada tahun 2010 sebesar Rp246,964,238 naik menjadi Rp907,388,986 pada tahun 2019. Peningkatan ini terjadi karena adanya dana yang pengembalian sering tidak tepat waktu serta kurangnya itikad baik dari pada debitur untuk mengembalikan dana yang sudah di berikan oleh 
Bank, oleh karena itu Bank BRI banyak mengalami kerugian dan hal ini merupakan ancaman bagi pihak Bank, jika tidak segera mendapatkan solusi maka akan berdampak bahaya pada Bank BRI, bagaiman tidak menigkatnya NPL ini jika di biarkan secara terus menerus akan memberikan negative pada Bank tersebut yang mengakibatkan Bank tersebut tidak akan berkembang sehat.

Melalui manajemen yang baik dalam berbagai kegiatan operasional Bank terutama untuk hal-hal yang terkait dengan kredit ini akan membantu menjaga kestabilan kondisi dalam Bank. NPL bisa memberikan pengaruh besar pada Bank. Jika di biarkan, maka yang pasti akan berdampak pada penyaluran kredit pada periode berikutnya. Sedangkan kredit yang disalurkan oleh bank merupakan pendapatan terbesar bank dari penerimaan bunga kredit. Apabila pemberian kredit berjalan dengan baik, maka bunga kredit dapat mencapai $70 \%$ sampai $90 \%$ dari keseluruhan pendapatan bank (Firdaus dan Ariyanti, 2011). Jadi, semakin banyak kredit yang disalurkan maka pendapatan bunga kredit juga akan banyak, hal ini sangat berperan penting dalam meningkatkan laba bank. Makin banyak kredit yang disalurkan, maka makin besar pula perolehan laba dari bidang ini (Kasmir, 2014). Kredit yang diberikan bank di dalamnya melekat risiko nasabah tidak dapat memenuhi kewajiban jatuh tempo yang menimbulkan kredit macet atau kredit bermasalah (Non Performing Loan). NPL mencerminkan kesulitan pelunasan pinjaman yang telah jatuh tempo oleh debitur. Menurut Sigid (2014) NPL adalah rasio yang menunjukkan pinjaman yang mengalami kesulitan pelunasan akibat adanya faktor kesenjangan dan faktor eksternal di luar kemampuan kendali debitur. Jika rasio NPL semakin tinggi maka semakin buruk kualitas kredit bank yang disebabkan oleh kerugian tingkat pengembalian kredit macet, yang pada akhirnya akan menurunkan laba bank. Dalam hal ini Bank Indonesia menetapkan bahwa tingkat NPL yang wajar bagi bank adalah $\leq 5 \%$.

Penelitian terkait NPL pada perbankan sebelumnya pernah dilakukan oleh Kurniati dan Nurhayati (2020), Hamka (2021), Handayani (2018) dan Firmansyah (2019). Tujuan dari penelitian ini adalah untuk mengetahui dan menganalisis seberapa besar kredit bermasalah dilihat dari standar Non Per forming Loan (NPL) pada PT. Bank BRI Tbk.

Hipotesis Penelitian

Menurut Sugiyono (2013) Hipotesis adalah jawaban sementara terhadap rumusan masalah penelitian, di mana rumusan masalah telah dinyatakan dalam kalimat pertanyaan. Hipotesis tersebut dirumuskan dalam bentuk hipotesis statistik dapat diajukan hipotesis sebagai berikut:

H0 : $\mu \geq 5 \%$ : Diduga Non Performing Loan (NPL) pada bank BRI berada diatas standar kriteria yang ditetapkan $5 \%$ di katakan tidak baik.

Ha : $\mu \leq 5 \%$ : Diduga Non Performing Loan (NPL) pada bank BRI berada dibawah standar kriteria yang ditetapkan $5 \%$ di katakana baik.

\section{METODE}

Jenis penelitian yang digunakan dalam penelitian ini adalah penelitian deskriptif. Penelitian deskriptif adalah penelitian yang dilakukan untuk mengetahui nilai variabel mandiri, baik satu variabel atau lebih (independen) tanpa membuat perbandingan atau menghubungkan antara variabel satu dengan variabel yang lain (Sugiyono, 2013). Dalam penelitian ini dibahas kredit bermasalah dilihat dari standar Non Performing Loan (NPL) pada PT. Bank BRI Tbk.

Populasi dalam penelitian ini adalah berupa laporan keuangan pada PT. Bank BRI Tbk. selama 30 Tahun yaitu dari Tahun 1989-2019. Sedangkan sampel yang digunakan merupakan lapoan keuangan PT. Bank BRI tbk. selama 10 tahun dari tahun 2010-2019. Teknik sampling digunakan teknik Purposive 
Sampling. Sumber data dalama penelitian ini adalah laporan tahunan PT. Bank BRI Tbk yaitu kolektibilitas piutang bank terdiri atas jumlah kredit bermasalah dan total kredit yang disalurkan. Kriteria pengambilan sampel yaitu ketersediaan data yang update untuk penelitian. Teknik pengumpulan data yang digunakan yaitu Studi Pustaka, dan dokumentasi. Adapun teknik analisis yang digunakan dalam penelitian ini adalah dengan menganalisis Non Performing Loan (NPL) pada PT. Bank BRI Tbk. Adapun uji hipotesis statistik dengan menggunakan T-test One sample.

\section{HASIL DAN PEMBAHASAN}

\section{Analisis Teoritis}

Besar Non Performing Loan (NPL) pada Bank Rakyat Indonesia (BRI) dari tahun 2010 sampai dengan tahun 2019 dapat di lihat di tabel di bawah ini:

Tabel 2. Data Non Performing Loan (NPL) pada Bank rakyat indonesia (BRI)

\begin{tabular}{ccccc}
\hline Tahun & Kredit Bermasalah & Total Kredit & NPL\% & Kriteria \\
\hline 2010 & $\operatorname{Rp~6,865,709}$ & $\operatorname{Rp~246,964,238}$ & 2.78 & Baik \\
\hline 2011 & $\operatorname{Rp~6,522,422}$ & $\operatorname{Rp~283,583,198}$ & 2.30 & Baik \\
\hline 2012 & $\operatorname{Rp~6,203,863}$ & $\operatorname{Rp~348,227,188}$ & 1.78 & Sangat Baik \\
\hline 2013 & $\operatorname{Rp~6,654,494}$ & $\operatorname{Rp~430,617,872~}$ & 1.55 & Sangat Baik \\
\hline 2014 & $\operatorname{Rp~8,271,125}$ & $\operatorname{Rp~490,402,708}$ & 1.69 & Sangat Baik \\
\hline 2015 & $\operatorname{Rp~11,267,382}$ & $\operatorname{Rp~558,436,016}$ & 2.02 & Baik \\
\hline 2016 & $\operatorname{Rp~12,882,913}$ & $\operatorname{Rp~635,291,221}$ & 2.03 & Baik \\
\hline 2017 & $\operatorname{Rp~14,862,646}$ & $\operatorname{Rp~708,001,045}$ & 2.10 & Baik \\
\hline 2018 & $\operatorname{Rp~17,232,672}$ & $\operatorname{Rp~804,338,433}$ & 2.14 & Baik \\
\hline 2019 & $\operatorname{Rp~23,773,591}$ & $\operatorname{Rp~907,388,986}$ & 2.62 & Baik
\end{tabular}

Sumber www.bankbri.co.id

Dari tabel 3 dapat di ketahui pada tahun 2010 dan 2011 NPL berada pada posisi Baik karena nilai NPL > dari $2 \%$ yaitu $2.78 \%$ dan 2.3\%. Namun pada tahun 2012-2014 berada pada posisi yang Sangat Baik karena nilai NPL < dari $2 \%$ yaitu $1.78 \%$ pada tahun 2012, $1.55 \%$ pada tahun 2013, dan $1.69 \%$ pada tahun 2014, sementara itu pada tahun 2015-2019 terjadi perubahan posisi yaitu kembali pada posisi Baik karena nilai NPL > dari 2\% yaitu 2.02 \% pada tahun 2015, $2.03 \%$ pada tahun 2016, 2.1 pada tahun 2017, $2.14 \%$ pada tahun 2018, dan pada tahun 2019 NPL mencapai nilai $2.62 \%$.

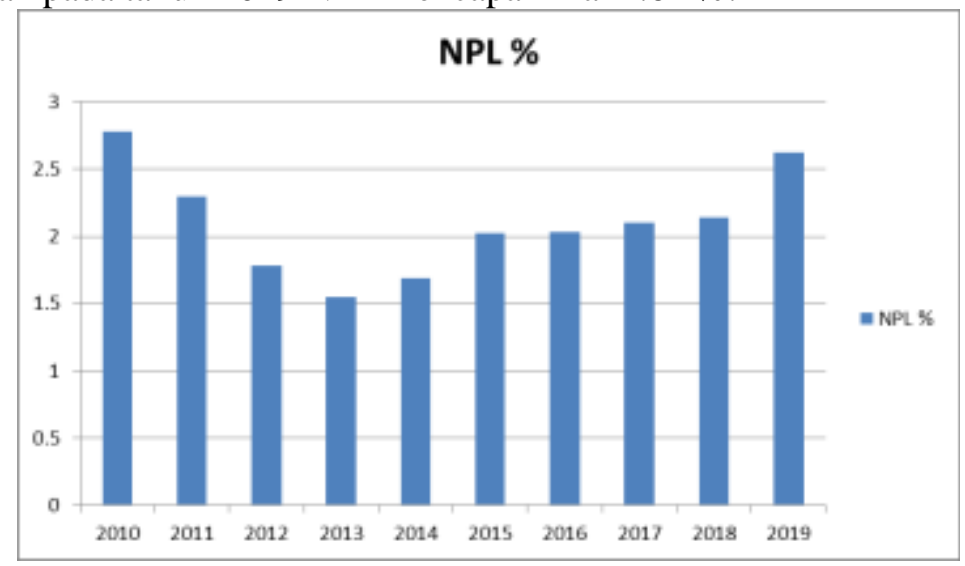

Grafik 1. Non Performing Loan (NPL) 
Dari grafik 1 diatas, nilai NPL dari tahun 2010-2019 mengalami fluktuatif dimana dari tahun 2010-2013 selalu mengalami penurunan. Namun pada tahun 2014-2019 mengalami peningkatan.

\section{Analisa Statistik (Uji t)}

Data yang telah didapatkan dalam penelitian ini akan dianalisis dengan menggunakan rumus t-test satu sampel. Menurut Sugiyono (2012), rumus t-test satu sampel, Adapun langkah-langkah perhitungan t-test satu sampel dengan nilai $\mu_{0}=5 \%$, serta tingkat signifikasi 0.05 pada uji pihak kiri dengan mengunakan SPSS 26.0 adalah sebagai berikut :

Tabel 3. One Sample Statistik

One-Sample Statistics

\begin{tabular}{ccccr}
\hline & N & Mean & Std. Deviation & Std. Error Mean \\
\hline NPL & 10 & 2.1010 & .38854 & .12287 \\
\hline \multicolumn{4}{c}{ Sumber data : data yang diolah SPSS } & 26.0
\end{tabular}

Kemudia semua nilai tersebut di subtitusikan ke dalam rumus t-test satu sampel dengan menggunakan SPSS 26.0 adalah sebagai berikut :

Tabel 4. One Sample Test

One-Sample Test

\begin{tabular}{|c|c|c|c|c|c|c|}
\hline & \multicolumn{6}{|c|}{ Test Value $=5$} \\
\hline & \multirow[b]{2}{*}{$\mathrm{T}$} & \multirow[b]{2}{*}{ df } & \multirow[b]{2}{*}{ Sig. (2-tailed) } & \multirow{2}{*}{$\begin{array}{c}\text { Mean } \\
\text { Difference }\end{array}$} & \multicolumn{2}{|c|}{ 95\% Confidence Interval of the Difference } \\
\hline & & & & & Lower & Upper \\
\hline NPL & -23.594 & 9 & .000 & -2.89900 & -3.1769 & -2.6211 \\
\hline
\end{tabular}

Berdasarkan hasil olahan data SPSS diatas diperoleh hasil bahwa nilai t hitung variabel NPL adalah sebesar - 23.594 dan nilai t tabel sebesar 1.833. Untuk membuktikan hipotesis dalam penelitian ini yaitu dengan membandingkan besarnya nilai ttabel dengan thitung dengan uji pihak kiri, dengan hipotesis sebagai berikut: "Diduga Non Performing Loan (NPL) pada PT. Bank BRI berada dibawah standar kriteria yang ditetapkan 5\%". Pada taraf signifikansi $0,05(\rho=95 \%)$, maka $\mathrm{dk}=\mathrm{n}-\mathrm{k}$ atau $\mathrm{dk}=10-1=9$, besarnya $\mathrm{t}$ tabel $=1.833$. Dengan membandingkan $\mathrm{t}$ hitung dengan $\mathrm{t}$ tabel, ternyata nilai $\mathrm{t}$ hitung lebih besar dari pada $t$ tabel yaitu $(-23,594<1,833)$, maka Ho ditolak dan Ha diterima, dengan taraf signifikansi $0,05(\rho=95 \%)$ uji pihak kiri. Sehingga hipotesis yang diterima menyatakan "Diduga Non Performing Loan (NPL) pada Bank BRI berada dibawah standar kriteria yang ditetapkan 5\% di katakana Baik". Hasil penelitian ini sejalan dengan penelitian yang dilakukan oleh Kurniati dan Nurhayati (2020).

\section{SIMPULAN}

Berdasarkan hasil analisis dan pengujian hipotesis maka dapat di tarik kesimpulan dalam penelitian ini yaitu menyatakan bahwa Non Performing Loan (NPL) pada Bank BRI berada dibawah standar kriteria yang ditetapkan 5\% di katakana Baik.

\section{Saran}

Penelitian ini terbatas hanya melakukan analisis deskripsi NPL pada satu bank dengan periode waktu 10 tahun. Untuk penelitian yang selanjutnya diharapkan dapat menambah beberapa variable baru seperti CAR, NIM dan LDR serta menggunakan objek lain. 


\section{Ucapan Terima Kasih}

Ucapan terima kasih terbesar saya pada Allah SWT yang masih memberikan udara kepada saya, dan ucapan penuh cinta kepada dua orang tua saya, serta semua kalangan yang telah membantu saya dalam menyelesaikan skripsi ini.

\section{DAFTAR PUSTAKA}

Firdaus, Rachmat dan Ariyanti, Maya, 2011. Manajemen Perkreditan Bank Umum (Teori, Masalah, Kebijakan dan Aplikasinya Lengkap dengan Analisis Kredit), Bandung : ALFABETA

Firmansyah, A. (2019). Analisis Kredit Bermasalah Dilihat Dari Standar Non Performing Loan (NPL) Pada PT. Bank Perkreditan Rakyat (BPR) Prima Mulia Anugrah Cabang Padang.

Hamka, H. (2021). Pengaruh Non Performing Loan (Npl) Terhadap Profitabilitas Pada Pt. Bank Mandiri Persero Tbk. Yang Terdaftar Di Bursa Efek Indonesia (BEI). PAY Jurnal Keuangan dan Perbankan, 3(1), 7-15.

Handayani, A. (2018). Pengaruh DPK, NPL dan ROA Terhadap Penyakuran Kredit Pada Bank Umum Yang Terdaftar Di Bursa Efek Indonesia Periode 2011-2014. Jurnal Penelitian Ekonomi dan Akuntansi. Vol. 3 (1).

Haryanto dan Saparso. 2018. Pertumbuhan dan Hasil Cabai Merah pada Berbagai Metode Irigasi dan Pemberian Pupuk Kandang di Wilayah Pesisir Pantai. Universitas Jenderal Soedirman : $11 \mathrm{hlm}$

Hosen, Muhammad Nadratuzzaman dan Rahmawati, Rafika. 2014. Analisis Efisiensi, Profitabilitas, dan Kesehatan Bank Umum Syariah di Indonesia Periode 2010-2013. Jurnal Keuangan dan Perbankan Vol. 16 No. 2 Desember 2014.

Kasmir. (2013). “Analisis Laporan Keuangan”. Edisi 1. Cetakan ke-6, Jakarta: Rajawali Pers , (2014). Bank dan Lembaga Keuangan Lainnya, Jakarta : PT RajaGrafindo Persada

Kurniati, T., \& Nurhayati, N. (2020). Analisis Kredit Bermasalah Dilihat Dari Standar Non Performing Loan (NPL) Pada Pt. Bank Mandiri (Persero) TBK. Inovator, 9(1), 17-22.

Ramadhany, Citra, 2017. "Pengaruh Pemberian Kredit dan Non Performing Loan (NPL) Terhadap Profitabilitas Pada Bank Rakyat Indonesia Periode 2006-2015", Vol 4 no.1.

Sigid, Ahmad, 2014. "Analisis Pengaruh Kredit dan Non Performing Loan (NPL) Terhadap Profitabilitas Pada Bank Umum Milik Pemerintah", Jurnal Ilmiah Mahasiswa FEB Brawijaya, Vol 2 no.2.

Sugiyono. 2013, Metode Penelitian Kuantitatif Kualitatif dan R\&D; Penerbit CV Alfabeta, Bandung. 